\title{
Experimental design for assessment of electrokinetically enhanced delivery of lactate and bacteria in 1,2-cis-dichloroethylene contaminated limestone
}

Hyldegaard, Bente Højlund; Nedergaard, L. W.; Ottosen, Lisbeth; Riis, Charlotte E.; Broholm, Mette Martina

\author{
Published in: \\ Environmental Technology \& Innovation
}

Link to article, DOI:

10.1016/j.eti.2015.04.006

Publication date:

2015

Document Version

Peer reviewed version

Link back to DTU Orbit

Citation (APA):

Hyldegaard, B. H., Nedergaard, L. W., Ottosen, L., Riis, C. E., \& Broholm, M. M. (2015). Experimental design for assessment of electrokinetically enhanced delivery of lactate and bacteria in 1,2-cis-dichloroethylene contaminated limestone. Environmental Technology \& Innovation, 4, 73-81.

https://doi.org/10.1016/j.eti.2015.04.006

\section{General rights}

Copyright and moral rights for the publications made accessible in the public portal are retained by the authors and/or other copyright owners and it is a condition of accessing publications that users recognise and abide by the legal requirements associated with these rights.

- Users may download and print one copy of any publication from the public portal for the purpose of private study or research.

- You may not further distribute the material or use it for any profit-making activity or commercial gain

- You may freely distribute the URL identifying the publication in the public portal 


\title{
Experimental design for assessment of electrokinetically enhanced delivery of lactate and bacteria in 1,2-cis-dichloroethylene contaminated limestone
}

\author{
Bente H. Hansen ${ }^{\mathrm{a}}$, Laerke W. Nedergaard ${ }^{\mathrm{a}}$, Lisbeth M. Ottosen ${ }^{\mathrm{a}}$, Charlotte Riis ${ }^{\mathrm{b}}$, Mette M. \\ Broholm $^{\mathrm{a}}$
}

${ }^{a}$ Technical University of Denmark, Kgs. Lyngby, Denmark

${ }^{b}$ NIRAS A/S, Alleroed, Denmark

\section{Highlights}

- Electrokinetically induced delivery of amendments in bryozoan limestone is proposed.

- For the application, an experimental set-up was successfully designed and evaluated.

- Fermentation of donor indicated successful pH control and anaerobic conditions.

- Enhanced delivery of lactate and bacteria by electromigration and electrophoresis.

- Essential contact between bacteria, donor and contaminant achieved within matrix.

\begin{abstract}
Bacterial dechlorination of chlorinated solvents often causes accumulation of the intermediate cisDCE. Back diffusion of e.g. cis-DCE, due to the dual porosity of limestone, often limits the remediation efficiency. A remediation scheme capable of establishing contact between contaminant, degrading bacteria and electron donor within the low permeable limestone matrix is required. The technology EK-BIO, which combines enhanced reductive dechlorination and electrokinetics (EK), was assessed. This novel technology has not previously been tested in limestone. An experimental set-up was designed to meet the requirements of anaerobic bacteria and to manage the volatile contaminants and extreme $\mathrm{pH}$ development prompted by electrolysis. The experimental set-up was tested and recommendations for design improvements presented. In this study, supplementary methods were developed for e.g. sampling of intact bryozoan limestone cores and for saturation and contamination of the cores with cis-DCE. EK induced transport processes for delivery of the donor lactate and mixed bacteria culture KB-1 ${ }^{\circledR}$ were studied. EK was shown to enhance delivery of lactate and bacteria resulting in fermentation of lactate in the limestone. Lactate was delivered by electromigration causing an increase in electric conductivity. No indications of establishment of electroosmotic flow in limestone were observed. Presence of specific cis-DCE degraders, Dehalococcoides, in the limestone could not be verified. However, the results indicated that fermentative bacteria were distributed by electrophoresis. This study suggests that EK application can establish the essential contact and overcome back diffusion. Thereby, EK-BIO may be superior to advection-based technologies for bioremediation of chlorinated solvent contaminated limestone matrices.
\end{abstract}




\title{
Experimental design for assessment of electrokinetically enhanced delivery of lactate and bacteria in 1,2-cis-dichloroethylene contaminated limestone
}

\author{
Bente H. Hansen ${ }^{\mathrm{a}}$, Laerke W. Nedergaard ${ }^{\mathrm{a}}$, Lisbeth M. Ottosen ${ }^{\mathrm{a}}$, Charlotte Riis ${ }^{\mathrm{b}}$, Mette M. \\ Broholm $^{\text {a }}$ \\ ${ }^{a}$ Technical University of Denmark, Kgs. Lyngby, Denmark \\ ${ }^{b}$ NIRAS A/S, Alleroed, Denmark
}

\begin{abstract}
Bacterial dechlorination of chlorinated solvents often causes accumulation of the intermediate cisDCE. Back diffusion of e.g. cis-DCE, due to the dual porosity of limestone, often limits the remediation efficiency. A remediation scheme capable of establishing contact between contaminant, degrading bacteria and electron donor within the low permeable limestone matrix is required. The technology EK-BIO, which combines enhanced reductive dechlorination and electrokinetics (EK), was assessed. This novel technology has not previously been tested in limestone. An experimental set-up was designed to meet the requirements of anaerobic bacteria and to manage the volatile contaminants and extreme $\mathrm{pH}$ development prompted by electrolysis. The experimental set-up was tested and recommendations for design improvements presented. In this study, supplementary methods were developed for e.g. sampling of intact bryozoan limestone cores and for saturation and contamination of the cores with cis-DCE. EK induced transport processes for delivery of the donor lactate and mixed bacteria culture KB-1 ${ }^{\circledR}$ were studied. EK was shown to enhance delivery of lactate and bacteria resulting in fermentation of lactate in the limestone. Lactate was delivered by electromigration causing an increase in electric conductivity. No indications of establishment of electroosmotic flow in limestone were observed. Presence of specific cis-DCE degraders, Dehalococcoides, in the limestone could not be verified. However, the results indicated that fermentative bacteria were distributed by electrophoresis. This study suggests that EK application can establish the essential contact and overcome back diffusion. Thereby, EK-BIO may be superior to advection-based technologies for bioremediation of chlorinated solvent contaminated limestone matrices.
\end{abstract}

\section{Keywords}

Bioremediation

Bryozoan limestone

Chlorinated solvent

Electrokinetic

Pore throat size

\section{Introduction}

Leakage of chlorinated solvents into limestone aquifers from contamination in overlying deposits and long-lasting back diffusion from the limestone matrix pose a threat to groundwater resources $[1,2$, 3]. In Denmark, approximately one third of the groundwater, which is used for drinking water, is extracted from limestone aquifers [4].

Assessment and treatment of groundwater contaminated with chlorinated solvents is a challenge due to the related physiochemical properties and transport mechanisms [5,6]. Dechlorination of PCE and TCE often accumulates the intermediate cis-DCE due to absence of the specific degraders Dehalococcoides (Dhc) [7]. In low permeable media, such as the limestone matrix, one relevant remediation technique is enhanced reductive dechlorination, where a fermentable carbon source, e.g. lactate, is injected together with a bacterial culture containing Dhc carrying the vcrA gene to create optimal conditions for biological degradation of chlorinated solvents to the non-harmful compounds 
ethene and ethane [8,9]. Transport into the finest pores by advection-based techniques such as injection in boreholes and cross recirculation is slow due to diffusion limited transport in the matrix. This delays establishment of the essential contact between the contaminant and the bioremediation amendments; electron donor and degrading bacteria [3,9,10].

Electrokinetics (EK) has shown potential for counteracting the transport limitations in low permeable media, such as clay, by application of a low-level direct current (DC) $[11,12,13,14]$. The unique transport processes offered by EK include electromigration (EM) - transport of charged ions, electroosmotic flow (EOF) - transport of pore fluid, and electrophoresis (EP) - transport of charged colloids $[12,15,16]$ (Fig. 1). In addition, electrolysis occurs at the electrodes, generating an aerobic and acidic environment at the anode, whereas reduced and alkaline conditions evolve at the cathode $[17,18]$. Such conditions can be severe for the strict anaerobic bacteria Dhc [19,20,21].
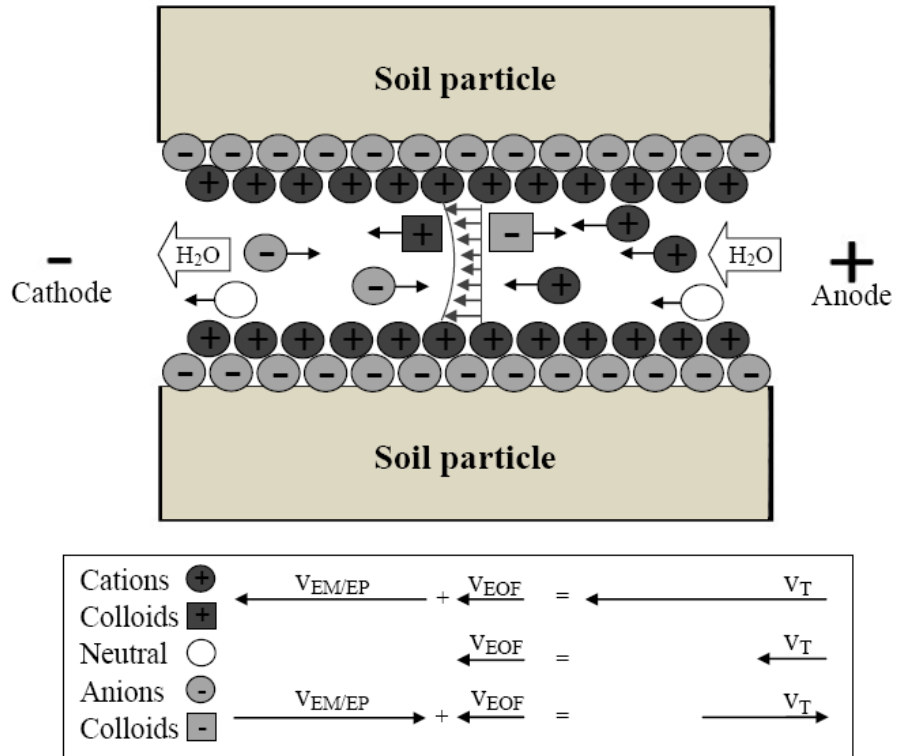

Fig. 1. Soil particles may have a negatively charged surface, which attracts positively charged ions. A diffuse double layer is created, which forms the foundation for EOF. The direction of EOF is represented by $\mathrm{H}_{2} \mathrm{O}$-arrows and can drag along neutral species (white circular shapes) such as chlorinated ethenes. The varying magnitude of EOF within the pore throat is shown by grey arrows. Direction of EM is shown for anions (light circular shapes) and cations (dark circular shapes). EP of negatively and positively charged colloids is shown as light and dark squares, respectively. Direction and size of velocity vectors for species present in the system affected by either EM or EP ( $\left.\mathrm{V}_{\mathrm{EM} / \mathrm{EP}}\right)$ and EOF $\left(\mathrm{V}_{\mathrm{EOF}}\right)$ are included along with a total transport direction for the specie $\left(\mathrm{v}_{\mathrm{T}}\right)$. The direction and magnitude of the total transport vector is geologic media specific.

Generally, EM is the dominating transport mechanism in an electric field [12,17,22]. Rates of EM from 10 to 300 times that of mass transport by EOF have been observed in clay [17,22]. In limestone, it is uncertain whether EOF can be established [23]. EP is often a minor contributor to the overall transport [12].

A new technology, EK-BIO, combines enhanced reductive dechlorination and EK to attain more effective bioremediation in low permeable media $[16,24]$. The chlorinated solvents can be transformed electrochemically at the cathode to chloride ions and ethane [25] or form positively charged ion pairs with protons present in the dissolved phase [26]. Thus, chlorinated solvents can be subject to EM $[11,26]$.

Most bacterial strains carry a weak negatively charged cell surface at near neutral $\mathrm{pH}$ causing EP towards the anode $[19,27,28]$. However, the bacteria can also be subject to advection in the EOF in the opposite direction of EP [11,29]. Similarly, EM of the electron donor lactate can be retarded by EOF, but the negative charge of lactate is capable of establishing a net movement towards the anode $[11,14,30]$. At bench scale, EK has demonstrated net transport rates of lactate in clay of $1.8-3.7 \mathrm{~cm} \mathrm{~d}^{-1}$ $[11,14,30]$. In sand, rates for lactate of $5.0 \mathrm{~cm} \mathrm{~d}^{-1}$ have been observed [30]. Bench scale studies of EK-

Abbreviations: EK, electrokinetics; Dhc, Dehalococcoides; DC, direct current; EM, electromigration; EOF, electroosmotic flow; EP, electrophoresis. 
BIO in clay have demonstrated promising results and a full scale remediation is currently operating in Denmark [11,14,31].

Few field scale studies have been published on ERD of chlorinated solvents in limestone $[32,33,34]$. The main objective of this study is to design an experimental set-up for assessment of the potential for EK to deliver lactate and the culture KB- ${ }^{\circledR}$ into limestone contaminated with cis-DCE. This is the first study of EK-BIO in limestone. For the design and assessment, several supplementary techniques have been developed in this study for handling of the limestone cores, e.g. sampling of intact bryozoan limestone cores, saturation and contamination of cores under vacuum conditions, and suspension of limestone for analytical procedures.

\section{Materials and methods}

\subsection{Design of experimental set-up}

The experimental set-up was carefully developed and adapted to assess the application of EK-BIO in bryozoan limestone while meeting the special needs of the bacteria. The different compartments included in the experimental set-up and the major considerations behind the decisions on the final design are presented in the following. A comprehensive description is available in [35].

The limestone reactor was an acrylic cylinder with an inner diameter of $10.3 \mathrm{~cm}$ and a length of $20.3 \mathrm{~cm}$ (Fig. 2). The cylindrical shape was chosen to minimize boundary effects and facilitate the collection of intact limestone. The cores were wrapped in self vulcanizing tape to prevent boundary effects. Attached to each end of the cylinder were the acrylic electrode reservoirs with an inner diameter of $10.3 \mathrm{~cm}$ and a length of $5 \mathrm{~cm}$ resulting in working volumes of approximately $0.4 \mathrm{~L}$. Membranes, consisting of fabric and filter paper, were placed at the limestone core-electrode reservoir interface. Platinum coated titanium electrodes with a working area of $0.5 \mathrm{~cm}^{2}$ were placed in the electrode reservoirs and connected to a power supply regulated to a constant current of $39 \mathrm{~mA}(0.5$ $\mathrm{mA} \mathrm{cm}{ }^{-2}$ ). Another two electrodes were installed horizontally in the limestone matrix approximately 4 $\mathrm{cm}$ from the membranes, serving as voltage measurement ports. Fermentation locks were installed on top of the electrode reservoirs to allow for release of gasses produced at the electrodes due to electrolysis.

A mixing reservoir serving for neutralization of $\mathrm{pH}$ was connected to the reactor set-up through four connections and was magnetically stirred continuously in 24 hour operation. The system solution had a working volume of $10 \mathrm{~L}$ and contained the donor lactate $\left(10 \mathrm{~g} \mathrm{~L}^{-1}\right)$ and $\mathrm{KH}_{2} \mathrm{PO}_{4}\left(0.05 \mathrm{~g} \mathrm{~L}^{-1}\right)$, $\mathrm{K}_{2} \mathrm{HPO}_{4}\left(0.10 \mathrm{~g} \mathrm{~L}^{-1}\right)$ and $\left(\mathrm{NH}_{4}\right)_{2} \mathrm{SO}_{4}\left(0.50 \mathrm{~g} \mathrm{~L}^{-1}\right)$ to ensure availability of $\mathrm{N}$ and $\mathrm{P}$ for the bacteria. For the recirculation of the system solution, peristaltic pumps with a flow rate of $25 \mathrm{ml} \mathrm{min}^{-1}$ were applied to pump from the mixing reservoir into the two electrode reservoirs and back from the electrode reservoirs into the mixing reservoir. Keeping the conditions in the system anaerobic was important to ensure proper conditions for the strict anaerobic bacteria Dhc. Therefore, this key issue was carefully considered when designing the different components of the experimental set-up. All tubes and couplings were designed to fit tightly to prevent oxygen intrusion and all air filled compartments were flushed with nitrogen prior to assembling the experimental set-up.

Abbreviations: EK, electrokinetics; Dhc, Dehalococcoides; DC, direct current; EM, electromigration; EOF, electroosmotic flow; EP, electrophoresis. 


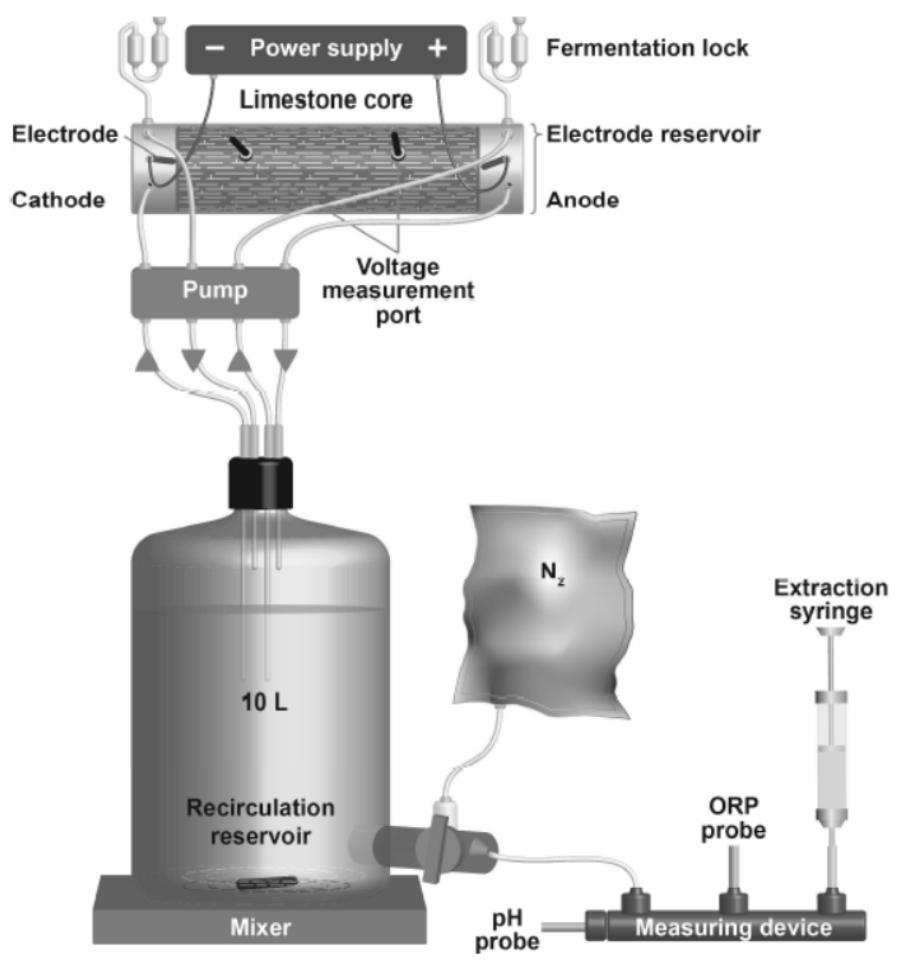

Fig. 2. A sketch of the experimental set-up designed for assessment of EK-BIO in limestone.

\subsection{Limestone characteristics}

Bryozoan limestone was retrieved in blocks from Faxe Quarry in Denmark. From one block, two limestone cores (D $9.87 \mathrm{~cm}$ and L $20.30 \mathrm{~cm}$ ) were sampled by drilling. The limestone was characterized using standardized methods [35]. Properties determined for the bryozoan limestone included a porosity of $38 \%$, a grain density of $2.72 \mathrm{~g} \mathrm{~cm}^{-3}$ and a hydraulic conductivity of $5.58 \cdot 10^{-11}$ $\mathrm{m} \mathrm{s}^{-1}$ (permeability of $5.8 \mathrm{mD}$ ). The mean pore size distribution, determined by a mercury injection method [35], was $0.72 \mu \mathrm{m}$ with a $95 \%$ confidence interval of 0.06 to $1.56 \mu \mathrm{m}$.

The bryozoan limestone was initially unsaturated and uncontaminated. Therefore, a vacuum technique was developed for saturation and contamination of the limestone cores with a cis-DCE solution. The cores were dried at $60^{\circ} \mathrm{C}$ for 24 hours and placed in a desiccator. The desiccator was connected to a vacuum pump (Alcatel $230 \mathrm{~V}$ ) and to a $9 \mathrm{~L}$ anaerobic solution containing $150 \mathrm{mg} \mathrm{L}^{-1}$ cis-DCE. Vacuum pumping of the desiccator lasted 5 hours after which the inlet for the solution was opened and the solution thereby transferred to the desiccator. A nitrogen filled gas bag allowed for compensation of the volume removed from the solution bottle. The achieved concentration of cis-DCE in the pore water was estimated to be minimum $5 \mathrm{mg} \mathrm{L}^{-1}$ based on a photo-ionization detector screening over the core.

\subsection{Experimental procedure}

Two reactors were assembled; one EK reactor to which a low DC was applied and one control reactor with no DC application. The experiment was operated for 31 days of which DC was applied for a total of 21 days. At day 0 DC was applied for delivery of lactate. However, from day 6 to day 14, the DC was turned off due to technical issues with the peristaltic pump. At day 17, $0.5 \mathrm{ml} \mathrm{KB}-1^{\circledR}$ culture with a Dhc cell concentration of $10^{11} \mathrm{~L}^{-1}$ (based on 16S rRNA gene quantification) was added followed by an acclimation period of 24 hours with no DC. An initial $24 \mathrm{~h} \mathrm{~d}^{-1}$ pumping strategy for recirculation of the system solution was adjusted at day 14 to an interval pumping strategy of 15 min pumping followed by one hour without. The interval pumping strategy reduced the system sensitivity 
towards fluctuating pumping rates and increased the pump-tubing longevity. A pumping rate of $25 \mathrm{ml}$ $\min ^{-1}$ for 15 minutes replaced the solution contained in the electrode reservoirs.

\subsection{Monitoring and analytical assessment}

Voltage measurements over the entire system and over the limestone core were performed daily during the 21 days of operation with application of DC. Sampling from the mixing reservoir was done directly from a tap placed in the lower part of the reservoir (Fig. 2). Weekly, samples were extracted for analysis of lactate and fermentation products. The samples were transferred to $1.5 \mathrm{ml}$ glass vials and analyzed by High-Performance Liquid Chromatography (HPLC) (Dionex ICE-AS1 9 x $250 \mathrm{~mm}$ ion exclusion column with a detection range of $0.1-10 \mathrm{~g} \mathrm{~L}^{-1}$ ). If lactate was consumed to a concentration below $5 \mathrm{~g} \mathrm{~L}^{-1}$, lactate was injected to reach initial concentration. $\mathrm{pH}$ and redox potential measurements were performed twice a week using a $\mathrm{pH}$ and a redox electrode both placed in a custom made measuring device, which could be connected directly to the tap in the mixing reservoir. During measurements, the solution from the mixing reservoir was drawn into the measuring device using a syringe.

At the end of the experiment, the cores were sacrificed. To evaluate the transport of lactate into the bryozoan limestone cores, limestone samples of $10 \mathrm{~g}$ were collected for every $1.3 \mathrm{~cm}$ of the limestone core. The limestone core was sliced using a saw blade and sampling was executed using an arch punch and a hammer. Each $10 \mathrm{~g}$ sample was suspended in $10 \mathrm{ml}$ demineralized water, shaken for 24 hours and filtered into $1.5 \mathrm{ml}$ vials for HPLC analysis. $\mathrm{pH}$ was measured on the supernatant using $\mathrm{pH}$ indicator strips. Limestone samples of $10 \mathrm{~g}$ for analysis of Dhc were collected using the same procedure. The samples were frozen and shipped to SiREM (Guelph, ON, Canada) for quantitative polymerase chain reaction analysis for Dhc and the $v c r$ A gene (Gene-Trac ${ }^{\circledR}$ ). A measure of total DNA in the limestone is analyzed using spectrophotometric quantification of genomic DNA extracted with a Nanodrop spectrophotometer. Degradation was not assessed, therefore analysis for cis-DCE or degradation products in the limestone were not performed.

\section{Results and discussion}

\subsection{Evaluation of the experimental set-up}

Handling, assembly and testing of the experimental set-up revealed benefits and challenges of the procedures and the design. Benefits included:

- Intact bryozoan limestone cores of required dimensions were obtained

- Successful saturation and contamination of limestone cores

- Boundary effects were avoided

- Effortless sampling and measurements of $\mathrm{pH}$ from mixing reservoirs

- The current density applied was sufficient

- Voltage development was successfully monitored with a multimeter

- No clogging issues occurred at the electrodes

- The recirculation pumping rate was adequate

Selecting an adequate technique for sampling of intact bryozoan limestone cores was crucial for the success of the EK-BIO experiment and its design. Studies indicate that sampling of limestone from the bedrock is problematic, time demanding and often creates non-uniform samples [36,37,38,39]. Coring of the limestone from blocks was not as problematic as anticipated. No visual cracks were created and the required dimensions were obtained. A cylindrical shape was optimal for handling and replication. In addition, soil repacking as used in EK-BIO studies with clay [11,14], which alters the properties of the soil matrix significantly, was avoided. The cylindrical shape minimizes the risk of boundary effects and by wrapping the cores in airtight and water proof self vulcanizing tape, optimal tight-fitting was achieved and no flow was observed at the boundaries.

Abbreviations: EK, electrokinetics; Dhc, Dehalococcoides; DC, direct current; EM, electromigration; EOF, electroosmotic flow; EP, electrophoresis. 
Sampling by coring of contaminated limestone without loss of material and/or contaminants is a challenge. In its place a method for saturation and contamination of the sampled bryozoan limestone cores was developed, utilizing vacuum properties. The method proved efficient for delivering cis-DCE into the limestone. The method was easy to implement and replicate. However, it remains unknown whether the contamination obtained in the micro pores is comparable to contamination in situ in limestone matrices after decades of exposure.

The techniques for sampling and measuring of $\mathrm{pH}$ in the mixing reservoirs were simple and of low disturbance to the experimental set-up. These measurements indicated efficient neutralization of $\mathrm{pH}$ by recirculation. However, the actual $\mathrm{pH}$ conditions in the electrode reservoirs remained unknown.

The applied current density of approximately $0.5 \mathrm{~mA} \mathrm{~cm}{ }^{-2}$ cross sectional area for the test of EKBIO was adapted from the studies in clay by $[11,14]$. When applied in limestone, the resulting voltages remained within technical capabilities of $<120 \mathrm{~V}$.

The configuration of the electrodes was optimal for application of DC and for simple monitoring of the voltage in the limestone by use of a multimeter. The working area of the electrodes was approximately $0.5 \mathrm{~cm}^{2}$ as opposed to $150 \mathrm{~cm}^{2}$ in [11]. However, the small electrode area applied in this study was not expected to influence the performance since the current was held constant: Electrodes with larger working areas establish enhanced contact between working solution and the electrode. Thus, the resistance over the boundary is reduced, implying a reduction in voltage [40]. A reduction in voltage also reduces the effect required since effect is a product of voltage and current. Thus, by using larger electrodes, the operational costs are theoretically lowered. However, since the current is held constant, the EM is constant and thereby also the efficiency of delivery of species. Clogging of the electrodes was not an issue. However, this might pose a challenge during long-term application.

For the recirculation, the pumping rate applied in [11] was adapted. A rate of $25 \mathrm{ml} \mathrm{min}^{-1}$ fulfilled the requirement of the solution dripping into the mixing reservoir and not leading to short circuiting of the system.

Challenges of the experimental design included:

- Operation of peristaltic pumps was instable and the service life of their tubing unsuitable for recirculation pumping

- Failure of fermentation locks occurred due to uneven pumping

- Maintenance of anaerobic conditions was challenged by pump operation issues

- Dead end redox electrode

The main issue during the experimental work for assessment of EK-BIO in limestone was instability of the recirculation pumping by use of peristaltic pumps. Peristaltic pumps were also used in the studies $[11,14]$. However, in contrast to their set-ups, the designed set-up required uniform pumping rates into and out of the electrode reservoirs. Since the pumping rates in the four tubes per peristaltic pump fluctuated highly, the combination of peristaltic pumps and fermentation locks was not optimal in that it allowed for drainage or overflow of the electrode reservoirs.

As a consequence of unstable pumping rates combined with the short service life of the tubing, the maintenance of anaerobic conditions turned out to be a real challenge: During drainage of the electrode reservoirs, atmospheric air was channeled through the fermentation lock and into the electrode reservoir. In [11,14] gas bags were installed for accumulation of generated gases, which also prevented influx of atmospheric air. Gas bags should be used only when one-way check valves are installed, which was not the case in the designed experimental set-up. Unfortunately, the redox electrode was malfunctioning. As a result, the redox conditions of the system could not be verified. To ensure anaerobic conditions, $0.24 \mathrm{~g} \mathrm{Na}_{2} \mathrm{SO}_{3}$ was injected for rapid consumption of oxygen.

Extreme pH conditions and aerobic conditions can cause inhibition of Dhc [20]. The design of EK$\mathrm{BIO}$ experiments to limit extreme $\mathrm{pH}$ is a challenge.

Abbreviations: EK, electrokinetics; Dhc, Dehalococcoides; DC, direct current; EM, electromigration; EOF, electroosmotic flow; EP, electrophoresis. 


\subsection{System $\mathrm{pH}$ conditions and effect on the bacteria}

In the mixing reservoir of the control and EK system, $\mathrm{pH}$ values in the range of 6.9-8.1 were observed, indicating effective neutralization of $\mathrm{pH}$ in the EK system. The observed $\mathrm{pH}$ range is suitable for the survival and growth of the bacteria and close to the optimum $\mathrm{pH}$ range for dechlorination [41]. However, the measurements made in the mixing reservoirs do not necessarily correspond to the $\mathrm{pH}$ values in the electrode reservoirs and/or the limestone. Calculations on $\mathrm{pH}$ development in the electrode reservoirs during interval pumping conditions indicated that $\mathrm{pH}$ in the cathode and anode reservoirs might reach values as high and low as 11 and 3, respectively. Despite the potentially extreme developments in $\mathrm{pH}$ as a consequence of the interval pumping, a similar strategy was employed in [11]. The study showed survival, growth and dehalorespiration by Dhc within the clay. Therefore, the impact on the bacteria in the limestone is not expected to have been severe in this study.

Acidic and alkaline fronts may develop within the limestone core due to EM of species generated during electrolysis. Therefore, $\mathrm{pH}$ was measured in the supernatant from the suspended limestone samples extracted from the cores. Note that the supernatant consisted of pore water diluted with demineralized water in a ratio of 1:6. Thus, the $\mathrm{pH}$ measured is an indicator of the relative evolution only. For the control system, the pH within the limestone core varied between 6.5 and 8.7 (Fig. 3A). For the EK system, the $\mathrm{pH}$ in the core was in the range of 7.9-8.7 and indicated a trend of an alkaline front until $6 \mathrm{~cm}$ within the core near the cathode (Fig. 3B). No acidic front was observed in the limestone near the anode.

\subsection{Lactate evolution and presence of bacteria}

In the mixing reservoirs, the lactate concentrations never declined to a level below $5 \mathrm{~g} \mathrm{~L}^{-1}$. Hence the addition of lactate to the solutions was not required. For the control system, near constant concentrations were observed, whereas in the EK system, the lactate results showed a small decrease in the concentration over time matched by an increase in the concentration of acetate. This indicates bacterial fermentation of lactate.

Generally, the concentrations of lactate in the limestone cores were lowest at the ends of the core, but no fermentation intermediates were detected. The deliveries of lactate remained below the maximum possible concentration of $10 \mathrm{~g} \mathrm{~L}^{-1}$ (Fig. 3), which might be explained by fermentation and the method for suspension. However, the levels reached in the limestone core of the EK system are exceeding $5 \mathrm{~g} \mathrm{~L}^{-1}$, which is the minimum acceptable concentration in the mixing reservoir.

In the control system, diffusion is the only expected transport mechanism. This is verified by the lactate concentrations within the core, which despite some variation indicate a trend of decrease from both ends of the core towards the centre (Fig. 3A). Lactate was observed throughout the limestone core suggesting a delivery rate significantly exceeding the estimated diffusive transport rate. This behavior may suggest internal inhomogeneity or microfracturing. For the EK system, a lactate concentration front was observed at 4-7 cm (Fig. 3B), which was not evident in the control. Therefore, the front must have been a consequence of EK. The front of lactate cannot be explained by EM since EM of lactate is in the direction towards the anode and the supply of lactate from the electrode reservoirs remained constant at $10 \mathrm{~g} \mathrm{~L}^{-1}$. Since lactate is observed in the limestone core near the anode, lactate must have been delivered by EM throughout the core.

Abbreviations: EK, electrokinetics; Dhc, Dehalococcoides; DC, direct current; EM, electromigration; EOF, electroosmotic flow; EP, electrophoresis. 


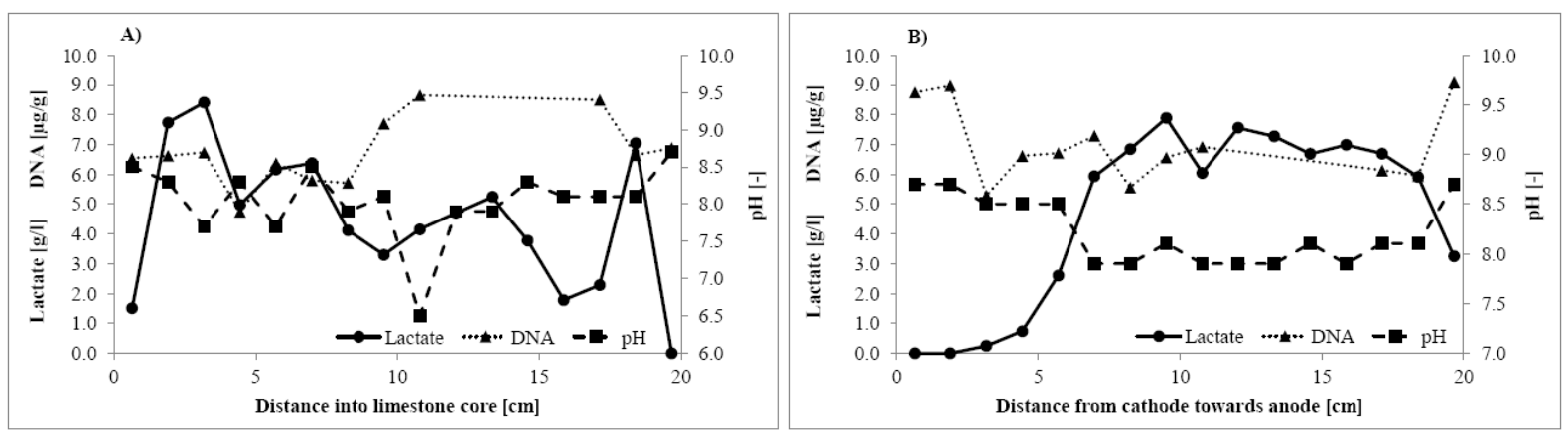

Fig. 3. A comparison of the content of lactate with measured total DNA and the evolution in $\mathrm{pH}$ in the matrix observed in the bryozoan limestone of A) control system and B) EK system.

The Gene-Trac ${ }^{\circledR}$ tests indicated that $D h c$ was below the detection limit. Due to the lack of Dhc detection, the evolution of total DNA concentration within the control and EK system was examined. The total DNA is a measure of active as well as inactive intact cells. Therefore, the total DNA count in Fig. 3 is not a direct measure of bacterial activity in the system. When comparing the development of lactate with the development of total DNA within the EK core (Fig. 3B), it appears that the DNA content is highest in the boundary areas where lactate is lowest. Thus, the mechanism that caused a decrease in lactate may be explained by bacterial activity with degradation of lactate. The lack of fermentation intermediates can be a result of complete fermentation. No formation of biofilm on e.g. electrodes or membranes was observed. This can be related to the short time frame of the experiment. In the control system, there were no indications of bacterial migration into the limestone core. An evenly distributed background level of aerobic bacteria may have been introduced during saturation of the limestone cores with tap water, which had been made anaerobic.

\subsection{EK induced transport processes of lactate}

The voltage drop was steep during the first days of the experiment after which it reached near steady state. The voltage drop reflected a decrease in the system resistance prompted by increased electrical conductivity and thereby EM and/or EP. The increased electrical conductivity was uniform across the system, which was also the case in [14]. The lactate concentrations observed in the limestone core of the EK system were generally higher and more evenly distributed than the concentrations observed in the control system (Fig. 3), which support that EM of lactate was taking place in the EK system.

Generally, it can be difficult to determine if EOF is established. EOF would result in transport of uncharged or weakly charged substances, such as bacteria, towards the cathode. In the limestone, no indications of EOF were observed. The limestone particles likely were uncharged as described in [23]. However, EOF can establish in limestone if changes in the charge of the limestone are created due to e.g. cation exchange [23]. Based on the development of lactate concentration in Fig. 3B, there was no indication of bacterial activity inside the limestone core near the anode except for the outer most part of the limestone core and thereby no indications of EOF. If EOF in limestone is weak, the indications of EOF may have been obscured by other transport processes.

EK was demonstrated to enhance the delivery of lactate. It was not possible to calculate a rate of EM due to complete break-through of lactate and a test down period of 8 days, where diffusion was the only transport mechanism. The migration of lactate in clay in $[11,14]$ with current densities similar to the one in this study, were $3.2 \mathrm{~cm} \mathrm{~d}^{-1}$ and $1.8-3.7 \mathrm{~cm} \mathrm{~d}^{-1}$, respectively. In clay, the soil particles are charged and thus EOF establishes [11,14]. However, EOF in the direction towards the cathode can counteract EM towards the anode [24]. Hence, in limestone where EOF is weak or non-existing, the rate of EM for lactate in limestone is expected to exceed the rates observed in clay. In sand, where EOF is less likely to establish [24], higher rates of EM for lactate of $5 \mathrm{~cm} \mathrm{~d}^{-1}$ have been observed [30].

Abbreviations: EK, electrokinetics; Dhc, Dehalococcoides; DC, direct current; EM, electromigration; EOF, electroosmotic flow; EP, electrophoresis. 
In the studied limestone, EOF was not observed. The delivery rates of lactate in limestone are thus expected to approximate those observed in sand.

\subsection{Evidence of electrophoresis of bacteria}

When comparing the distribution of lactate in the EK system with the $\mathrm{pH}$ development in the limestone core (Fig. 3B), a clear, but inverse correlation between the lactate concentrations and level of $\mathrm{pH}$ is observed. Generally, the $\mathrm{pH}$ in both the control and the EK system limestone cores exceeded the background level of 7.4. For the EK system, the higher values of $\mathrm{pH}$ in the vicinity of the cathode might be explained by EM of the alkaline front generated due to electrolysis. However, this is not adequate for explaining the observed increase in $\mathrm{pH}$ in the vicinity of the anode, where low $\mathrm{pH}$ is expected. Instead, the observed reverse correlation between lactate content and $\mathrm{pH}$ is likely evidence of bacterial activity based on ionic activity resulting from complete fermentation of sodium lactate at pH between 7.9 and 8.7, where $\mathrm{HCO}_{3}{ }^{-}$is the dominating specie (Eq. 1) [42]. This is in agreement with the findings of elevated DNA concentrations at the ends of the limestone core and approximately $2 \mathrm{~cm}$ into the core at the cathode end (Fig. 3B).

$$
2 \mathrm{C}_{3} \mathrm{H}_{5} \mathrm{O}_{3}^{-}+2 \mathrm{Na}^{+}+2 \mathrm{H}_{2} \mathrm{O} \rightarrow 3 \mathrm{CH}_{4}+\mathrm{CO}_{2}+2 \mathrm{Na}^{+}+2 \mathrm{HCO}_{3}^{-}
$$

For every mole of lactate reacted, a mole of $\mathrm{HCO}_{3}{ }^{-}$and the alkalinity of the system studied increased with one mole.

The limestone likely ensured efficient buffering of an acidic front generated at the anode. The increase in $\mathrm{pH}$ in the limestone near the anode can be explained by fermentation of lactate with generation of bicarbonate. Therefore, since no fermentation intermediates were measured, but the lactate content was low or absent in the boundary areas, complete fermentation of lactate by bacterial activity must have occurred in the EK system. This bacterial activity must be due to the fermentative bacteria in the injected KB- $1^{\circledR}$ culture, but it is not evidence of Dhc presence. That bacterial activity occurred is in agreement with detection of acetate within the mixing reservoir of the EK system.

The indication of lactate fermentation near the anode is possibly explained by bacteria adhering to the end of the limestone, which is verified by the higher DNA concentration detected in this location (Fig. 3B). Based on the lactate concentration and $\mathrm{pH}$ profiles in Fig. 3B, it appears EP was capable of transporting fermentative bacteria up to approximately $5 \mathrm{~cm}$ into the limestone core within the 12 days where KB- $1^{\circledR}$ had been subject to EK in the test. Fig. 4 is an illustration of the transport processes observed during the assessment of EK-BIO in limestone.

The shape of the lactate front likely is an indication of reversed diffusion towards the cathode initiated by the removal of lactate by bacterial activity partially counteracted by EM.

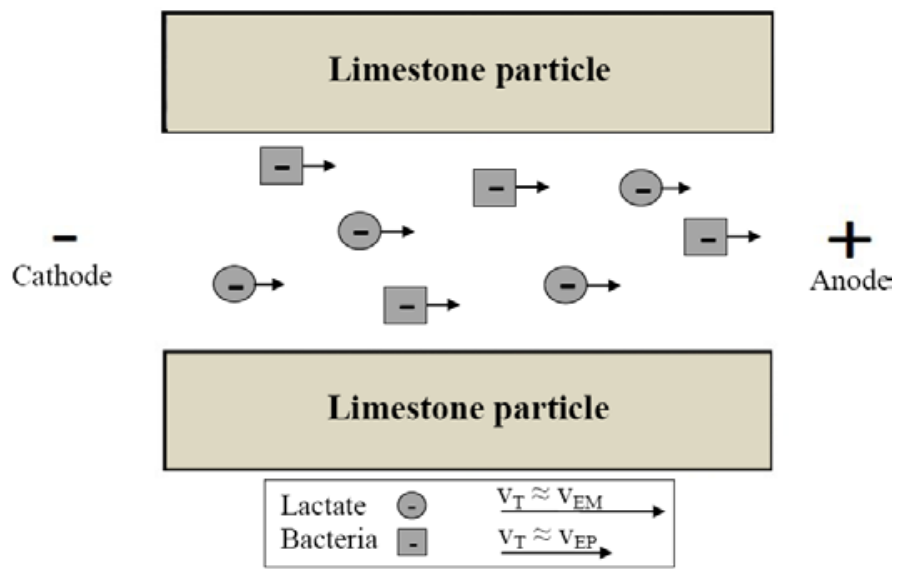

Fig. 4. A simplified illustration of transport processes observed during the EK-BIO experiment for lactate and bacteria in limestone. The processes include electromigration (EM) of lactate (circular shapes) and electrophoresis (EP) of bacteria

Abbreviations: EK, electrokinetics; Dhc, Dehalococcoides; DC, direct current; EM, electromigration; EOF, electroosmotic flow; EP, electrophoresis. 
(squares). EOF is not observed and mobilization of chlorinated solvents is not assessed. Direction and size of the total velocity vectors (vT) for species in the system are included. Drawing is not to scale and neglects presence of other ions.

For the control system, the development in lactate concentration and $\mathrm{pH}$ indicated fermentation in the limestone reservoir interface only. Hence, it appears that the bacteria did not migrate into the limestone core, but stayed at the end of the core within the 14 days where KB- ${ }^{\circledR}$ was present (Fig. 3A).

\subsection{Pore sizes in limestone versus Dhc sizes}

There is a lack of knowledge on EP and growth of bacteria in limestone. However, when comparing the pore sizes determined for the bryozoan limestone of $0.06-1.56 \mu \mathrm{m}$ and literature values for sizes of $D h c$ on $\leq 0.8-2 \mu \mathrm{m}[43,44,45]$, movement of bacteria within the limestone should be possible. In the experiments in this study, the presence of $D h c$ was not verified. The lack of detection of Dhc only showed that Dhc was not present in concentrations higher than the detection limit of the Gene-Trac ${ }^{\circledR}$ assay around $6.5 \cdot 10^{3}$ cells per gram limestone. For an inoculated concentration of $D h c$ of $5 \cdot 10^{6}$ cells per liter, a maximum theoretical concentration of $D h c$ in the limestone was $9.7 \cdot 10^{2}$ cells per gram limestone when growth is neglected. The theoretical maximum concentration assumes presence of bacteria in the entire pore space of the sample volume. A substantial amount of the measured pore throats in the limestone may have been significantly smaller than the reported sizes of bacteria. Therefore, the achievable cell concentration most likely was below the detection limit of the qPCR assay. Subsequent analysis of the samples for the gene vcrA revealed presence (detected, but below quantification level) of the gene vcrA at 3-4 cm into the limestone core in the EK system. Considering the low inoculated concentration of $D h c$, this result is very promising with respect to the transport of Dhc into limestone with EK. Also, bacteria have shown to be capable of morphological adaptation to facilitate migration and growth through channels smaller than their respective sizes [46]. Since the assessment of transport by EK observed in the performed experiments indicated significant migration of some bacteria by EP, it is believed that also Dhc has a potential to be transported by EP in limestone. Improve

\subsection{Suggestions for optimization of the experimental set-up}

The following proposals for optimization of the experimental set-up are mainly expected to ensure a more consistent operation of the experiment. In addition, the proposals are expected to improve the understanding of the system processes and response. The alterations are expected to optimize the conditions for the bacteria inoculated and thereby potentially enhance the growth. However, the alterations are not expected to impact the delivery of lactate.

Recirculation of the fluid in the mixing reservoirs is important for the control of $\mathrm{pH}$, but posed a significant challenge in the experimental set-up. A different pumping strategy could be applied, where only pumping into the electrode reservoirs is taking place and the pumping out of the electrode reservoirs is replaced with a simple system of overflow (Fig. 5). Such a strategy will make the system less sensitive to minor changes in pumping rates. Furthermore, the working volume of the electrode reservoirs should be increased to contain e.g. $5 \mathrm{~L}$ compared to $0.4 \mathrm{~L}$ used in this study. The volume of the mixing reservoir can then be reduced to $1 \mathrm{~L}$. This modification will increase the buffering capacity of the fluid and make the system less sensitive to pump breakdowns. To eliminate the impacts of fluctuating pumping rates, the electrode reservoirs should be designed to extend above the limestone core and contain a headspace.

Additional monitoring during the experiment would enhance the understanding of the system and the ongoing processes. $\mathrm{pH}$ measurements in the electrode reservoirs would give a better comprehension of the $\mathrm{pH}$ development and the efficiency of the recirculation mixing. Redox potentials should be measured directly in the mixing reservoir to verify reduced conditions. An additional option for detection of aerobic conditions is use of non-invasive optical oxygen sensors installed below the water level in the electrode reservoirs giving indications of oxygen produced by electrolysis and/or air intrusion.

Abbreviations: EK, electrokinetics; Dhc, Dehalococcoides; DC, direct current; EM, electromigration; EOF, electroosmotic flow; EP, electrophoresis. 


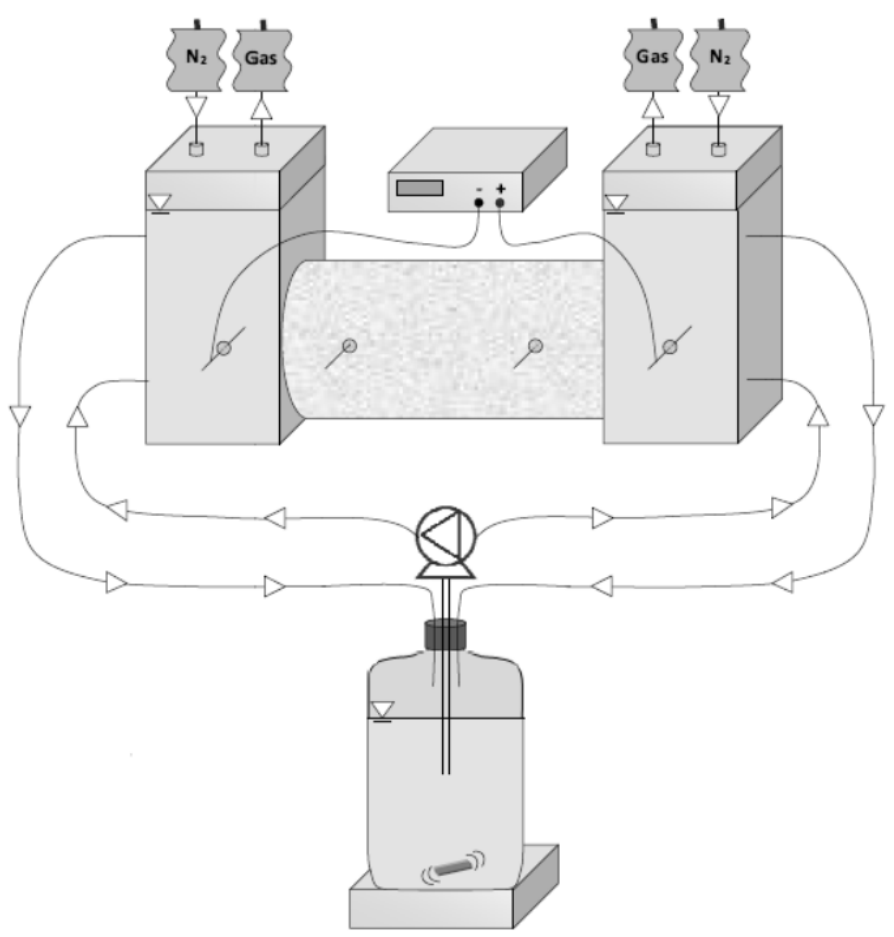

Fig. 5. A sketch of suggested improvements to the experimental design of EK-BIO in limestone. The electrode reservoirs are extended to $5 \mathrm{~L}$ each. Pumping takes place into the electrode reservoirs only due to overflow out of the electrode reservoirs. The mixing reservoir is reduced to $1 \mathrm{~L}$.

Fluid samples taken directly from the limestone core during the experiment, would provide more knowledge concerning the development in lactate and bacteria concentrations over time. This approach was applied in studies of EK-BIO in clay [11,14], however with limited success due to low fluid volume generation. The approach is less likely to be applicable for sampling in the bryozoan limestone matrix, which has a lower permeability than the clay studied. The method might also cause significant disturbance of the flow and thereby bias the results obtained in the experiment.

\section{Conclusions}

This study has added the value of a better understanding of processes in a complex system of EK$\mathrm{BIO}$ in a limestone matrix. An experimental set-up was successfully designed for the first application and assessment of EK-BIO in bryozoan limestone. The design proved to be successful despite some challenges with recirculation pumping of the electrode solution for neutralization of $\mathrm{pH}$. For future studies, modifications of the experimental design were suggested.

The preliminary study of EK induced transport processes of the donor lactate and the KB-1 ${ }^{\circledR}$ bacteria culture showed that the application of EK enhanced the delivery of both lactate and bacteria into the limestone. Lactate was transported in the bryozoan limestone core by EM. Presence of the specific degrader Dhc inside the limestone core above the detection limit of $6.5 \cdot 10^{3}$ cells per gram limestone could not be verified. However, bacterial activity resulting in fermentation of lactate and an increase in $\mathrm{pH}$ was observed inside the limestone. Thus, bacteria migrated with EP into the limestone. No indications of EOF occurrence were observed. A control reactor with no application of EK showed significant diffusive transport of lactate into the limestone, but resulted in uneven lactate distribution and showed no indications of bacteria transport into the limestone.

The pore size of the bryozoan limestone was in the range of 0.06-1.56 $\mu \mathrm{m}$ with a mean pore size of $0.72 \mu \mathrm{m}$. The bacteria strain Dhc should be able to live and grow in the bigger pores of the limestone based on its expected size range of $\leq 0.8-2 \mu \mathrm{m}$. This remains to be documented.

Abbreviations: EK, electrokinetics; Dhc, Dehalococcoides; DC, direct current; EM, electromigration; EOF, electroosmotic flow; EP, electrophoresis. 
This study indicates that EK is capable of creating the necessary contact between contaminant, donor and bacteria in the bryozoan limestone matrix. Thus, EK can potentially eliminate back diffusion limitations in a contaminated limestone aquifer. Therefore, shorter remediation timeframes are expected when implementing EK-BIO as a remediation technique in limestone aquifers. However, additional bench scale studies are required prior to field application e.g. with limestone samples from a contaminated site or with fractured limestone.

\section{Acknowledgements}

Conducted as a M.Sc. thesis at DTU this project was funded by the Capital Region of Denmark and SiREM.

\section{References}

[1] M.M. Broholm, G.S. Janniche, A.S. Fjordbøge, Characterization of DNAPL source zone architecture in clay till and limestone bedrock by integrated site investigations with innovative and current techniques. In $8^{\text {th }}$ IAHS International Groundwater Qulaity Conference (GQ13), Florida, (2013).

[2] K. Hinsby, T.F. Jensen, T. Bidstrup, European reference aquifers: The limestone aquifers around Copenhagen, Denmark. Report for the EU research projects ('BASELINE'): Natural baseline quality of European groundwater: A basis for aquifer management, GEUS (2007).

[3] D.H. Lipson, B.H. Kueper, M.J. Gefell, Matrix diffusion-derived plume attenuation in fractured bedrock, Ground Water 43 (2005) 30-39.

[4] E. Nygaard, Denmark, in: R.A. Downing, M. Price, G.P. Jones, (Eds.), The hydrogeology of the chalk of north-west Europe, Clarendon press, Oxford, 1993, pp. 186-207.

[5] I. Damgaard, P.L. Bjerg, C.S. Jacobsen, A. Tsitonaki, H. Kerm-Jespersen, M. Broholm. Performance of Full-Scale Enhanced Reductive Dechlorination in Clay Till. Groundwater Monitoring and Remediation 33 (2013) 48-61.

[6] J.F. Pankow, S. Fenstra, J.A. Cherry, M.C. Ryan, Dense chlorinated solvents in groundwater: Background and history of the problem, in: J.F. Pankow, J.A. Cherry, (Eds.), Dense chlorinated solvents and other DNAPLs in groundwater, Waterloo press, Oregon, 1996.

[7] P.K.H. Lee, D. Cheng, K.A. West, L. Alvarez-Cohen, J. He, Isolation of two new Dehalococcoides mccartyi strains with dissimilar dechlorination functions and their characterization by comparative genomics via microarray analysis, Environmental microbiology 15 (2013) 2293-2305.

[8] C. Scheutz, N.D. Durant, P. Dennis, M.H. Hansen, T. Jørgensen, R. Jakobsen, E.E. Cox, P.L. Bjerg, Concurrent ethene generation and growth of Dahalococcoides containing vinyl chloride reductive dehalogenase genes during an enhanced reductive dechlorination field demonstration, Environmental science and technology 42 (2008) 9302-9309.

[9] C. Scheutz, M.M. Broholm, N.D. Durant, E.B. Weeth, T.H. Jørgensen, P. Dennis, C.S. Jacobsen, E.E. Cox, J.C. Chambon, P.L. Bjerg, Field evaluation of biological enhanced reductive dechlorination of chloroethenes in clayey till, Environmental science and technology 44 (2010) 5134-5141.

[10] S.N. Venkatraman, J.R. Schuring, T.M. Boland, I.D. Bossert, D.S. Kosson, Application of pneumatic fracturing to enhance in situ bioremediation, Journal of soil contamination 7 (1998) 143162.

[11] X. Mao, J. Wang, A. Ciblak, E.E. Cox, C. Riis, M. Terkelsen, D.B. Gent, A.N. Alshawabkeh, Electrokinetic-enhanced bioaugmentation for remediation of chlorinated solvents contaminated clay, Journal of hazardous materials 213-214 (2012) 311-317.

[12] K.R. Reddy, Electrokinetik remediation of soils at complex contaminated sites: Technology status, challenges and opportunities, in: M. Manassero, A. Dominijanni, S. Foti, G. Musso (Eds.), Coupled phenomena in environmental geotechnics, CRS press, Taylor and Francis Group, 2013, pp. 131-147.

Abbreviations: EK, electrokinetics; Dhc, Dehalococcoides; DC, direct current; EM, electromigration; EOF, electroosmotic flow; EP, electrophoresis. 
[13] D.A. Reynolds, E.H. Jones, M. Gillen, M. Yusoff, D.G. Thomas, Electrokinetic migrations of permanganate through low-permeability media, Groundwater 46 (2008) 629-637.

[14] X. Wu, D.B. Gent, J.L. Davis, A.N. Alshwabkeh, Lactate injection by electric current for bioremediation of tetrachloroethylene in clay, Electrochimica Acta 86 (2012) 157-16.

[15] Y.B. Acar, M.F. Rabbi, E.E. Ozsu, Elektrokinetic injection of ammonium and sulphate ions into sand and kaolinite beds, Journal of geotechnical and geoenvironmental engineering 123 (1997) 239-249.

[16] A.N. Alshawabkeh, Electrokinetic soil remediation: Changes and opportunities. Separation Science and Technology 44 (2009) 2171-2187.

[17] Y. B. Acar, A.N. Alshawabkeh, Principles of elektrokinetic remediation, Environ. Sci. Technol 27 (1993) 2683-2647.

[18] N. Mosavat, E. Oh, G. Chai, A review of electrokinetic treatment technique for improving the engineering characteristics of low permeable problematic soils, International journal of GEOMATE 2 (2012) 266-271.

[19] M.F. DeFlaun, C.W. Condee, Electrokinetic transport of bacteria, Journal of hazardous materials 55 (1997)263-277.

[20] P. Dennis, S. Dworatzek, C. Repta, D. Graves, Aquifer pH neutralization for bioremediation of chlorinated solvents, Technical report, SiREM (2008).

[21] Parsons Coporation, Principles and practices of enhanced anaerobic bioremediation of chlorinated solvents, Air force center for environmental excellence (AFCEE) and naval facilities engineering service center (NFESC), Technical report (2014).

[22] K. Arnerdal, I. Neretnieks, Soil remediation using an electrokinetic method, in: Groundwater Quality. Groundwater Quality: Natural and enhanced restoration of groundwater pollution, 2002, pp. 361-367.

[23] M.M Alam, R. Ahsan, A.K. Shaik, I.L. Fabricius, Surface charge of calcite and its influence on the electrical conductivity in chalk, Imagine Our Future, SEG International Exposition and 80th Annual Meeting, Colorado (2010) 2686-2691.

[24] R.T. Gill, M.J. Harbottle, J.W.N. Smith, S.F. Thornton, Electrokinetic-enhanced bioremediation of organic contaminants: A review of processes and environmental applications, Chemosphere 107 (2014) 31-42.

[25] X. Mao, S. Yuan, N. Fallahpour, A. Ciblak, J. Howard, I. Padilla, R. Loch-Caruso, A.N. Alshawabkeh, Electrochemically induced dual reactive barriers for transformation of TCE and mixture of contaminants in groundwater, Environmental science and technology 46 (2012) 1200312011.

[26] G. Chen, E.A. Betterton, R.G. Arnold, W.P. Ela, Electrolytic reduction of trichloroethylene and chloroform at a Pt- or Pd-coated ceramic cathode, Journal of applied electrochemistry 33 (2002) 161-169.

[27] A.J. Acuña, O.H. Pucci, G.N. Pucci, Electrobioremediation of hydrocarbon contaminated soil from Patagonia Argentina, in: J.S. Gomes (Eds.), New technologies in the oil and gas industry, InTech, Patagonia, 2012, pp 29-48.

[28] I. Tahmasbian, A. Nasrazadan, Soil electrokinetic remediation and its effects on soil microbial activity - a review, African journal of microbiology research 6 (2001) 2233-2238.

[29] H. Lee, K. Lee, Bioremediation of diesel-contaminated soil by bacterial cells transported by electrokinetics, Journal of microbiology and biotechnology 11 (2001) 1038-1045.

[30] X. Wu, A.N. Alshwabkeh, D.B. Gent, S. Larson, J. Davis, Rates of lactate transformation and transport in soil under DC fields, ASCE Journal of geotechnical and geoenvironmental engineering 133 (2007) 1587-1596.

[31] NIRAS, Elektrokinetik og bakterier renser forurenet jord, NIRAS, Allerød, http://www.niras.dk/aktuelt/nyheder/2012/elektrokinetik-og-bakterier-renser-forurenet-jord.aspx (2012).

[32] P.G. Landry, P.R. Stone, Enhanced bioremediation of chlorinated solvents in karst limestone bedrock using sodium lactate, In 8th International in situ and on-site bioremediation symposium, Columbus (2005).

Abbreviations: EK, electrokinetics; Dhc, Dehalococcoides; DC, direct current; EM, electromigration; EOF, electroosmotic flow; EP, electrophoresis. 
[33] C.E. Riis, A.G. Christensen, A.P. Mortensen, H. Jannerup, Bioremediation of TCE in a fractured limestone aquifer using a novel horizontal passive biobarrier, Remediation Journal 20 (2010) 2743.

[34] C.E. Riis, M.H. Hansen, H. Husum , Stimuleret reduktiv dechlorering i kalkmagasin, Miljøprojekt nr. 1562, Miljøministeriet, København (2014).

[35] B.H. Hansen, L.W. Nedergaard, Experimental design and assessment of electrokinetically enhanced bioremediation of chlorinated solvents in limestone, Master thesis, Technical University of Denmark, Lyngby (2014).

[36] N. Claes, Water and chemical transport in limestone - merging measurement and modelling concepts at different scales, Master thesis, Aalborg University, Aalborg (2011).

[37] G. Thorsen, Sprækket kridt - gennemstrømningsforsøg, 11. nordiske geoteknikermøde, Dansk geoteknisk forening (1992).

[38] L. Mortensen, H. Lorenzen, Transport og reaktiv iltbarriere i kalkakvifer på Ferslev Byvej, Master thesis, Aalborg University, Aalborg (1999).

[39] C. Pedersen, M. Hørlük, Modellering af skalaafhængig stoftransport i opsprækket kalk, Master thesis, Aalborg University, Aalborg (2012).

[40] S. Furman, B. Parker, D.J.W. Escher, Decreasing electrode size and increasing efficiency of cardiac stimulation, Journal of Surgical Research 11 (1971) 105-110.

[41] P.J.M. Middeldorp, M.L.G.C. Lujiten, B.A. van der Pas, M.A. van Eekert, W.W.M. Kengen, G. Schraa, A.J.M. Stams, Anaerobic microbial reductive dehalogenation of chlorinated ethenes, Bioremediation Journal 3 (1999) 151-169.

[42] W.W. Nazaroff, L. Alvarez-Cohen, 3 Transformation Processes, in: W.W. Nazaroff, L. AlvarazCohen, (Eds.), Environmental engineering science, John Wiley \& Sons, Inc., California, 2001, pp. 76-158.

[43] L. Adrian, U. Szewzyk, J. Wecke, H. Görlsch, Bacterial dehalorespiration with chlorinated benzenes, Nature 408 (2000).

[44] D. Cheng, J. He, Isolation and characterization of "Dehalococcoides”sp. Strain MB, which dechlorinates tetrachloroethene to trans-1,2-dechloroethene, Applied ad environmental microbiology 75 (2009) 5910-5918.

[45] J. He, J. Sung, M.E. Dollhopf, B.Z. Fathepure, J.M. Tiedje, F.E. Löffler, Detoxification of vinyl chloride to ethane coupled to growth of an anaerobic bacterium, Nature 24 (2003) 62-65.

[46] K. Männik, R. Driessen, P. Galajda, J.E. Kaymer, C. Dekker, Bacterial growth and mobility in sub-micron constrictions, PNAS 100 (2009) 14861-14866.

Abbreviations: EK, electrokinetics; Dhc, Dehalococcoides; DC, direct current; EM, electromigration; EOF, electroosmotic flow; EP, electrophoresis. 